\title{
Zooplankton richness, abundance and biomass of two hypertrophic shallow lakes with different salinity in central Argentina
}

\author{
Santiago Andrés Echaniz, ${ }^{1,3}$, Alicia María Vignatti, \\ Gabriela Cecilia Cabrera ${ }^{1} \&$ Susana Beatriz José de Paggi ${ }^{2}$ \\ ${ }^{1}$ Facultad de Ciencias Exactas y Naturales, Universidad Nacional de La Pampa. Av. Uruguay 151, 6300, \\ Santa Rosa, provincia de La Pampa, República Argentina. http://www.exactas.unlpam.edu.ar \\ ${ }^{2}$ Consejo Nacional de Investigaciones Cientificas y Técnicas - CONICET, Instituto Nacional de \\ Limnología, Facultad de de Bioquímica y Ciencias Biológicas, Universidad Nacional del Litoral Ciudad \\ Universitaria, Paraje El Pozo, 3000, Santa Fe, provincia de Santa Fe, República Argentina. \\ http://www.inali.santafe-conicet.gov.ar \\ ${ }^{3}$ Corresponding author: Santiago Andrés Echaniz, email: sechaniz@cpenet.com.ar
}

ECHANIZ, S.A., VIGNATTI, A.M., CABRERA, G.C. \& PAGGI, S.B.J. Zooplankton richness, abundance and biomass of two hypertrophic shallow lakes with different salinity in central Argentina. Biota Neotrop. v. 12 (1): http://www.biotaneotropica.org.br/v12n2/en/abstract?article+bn00712022012

\begin{abstract}
The zooplankton of lakes is controlled by biological and physico-chemical parameters. Among the former, predation by fish can determine the replacement of large-sized species by small-sized ones and among the latter, salinity exerts negative effects on richness and abundance. Since it has been suggested that saline lakes without fishes have higher zooplankton biomass than low salinity ones, the aim of this study was to determine the richness, abundance and biomass of zooplankton in two lakes with different salinity and test the hypothesis that in the presence of zooplanktivorous fishes and at equal concentrations of nutrients and chlorophyll- $a$, saline lakes have higher biomass than those with low salinity. The study was conducted in two shallow lakes of the Province of La Pampa (central Argentina): a subsaline lake and a hyposaline lake, which shared high concentrations of chlorophyll- $a$ and total phosphorus, reduced transparency and presence of planktivorous fish. Zooplankton richness was different and higher in the subsaline lake, whereas abundance and total biomass were similar, even when the taxonomic groups were considered separately. It is suggested that the presence of a halotolerant planktivorous fish controlled the size of zooplankton due to the predation on larger species and prevented the development of higher biomass in the saline lake, which is an important difference from previously recorded situations. This study shows that, regardless of the differences in salinity, the top-down effect in the food chain may have been a factor that equalized the zooplankton biomass by allowing only the development of small species and highlights the possible importance of fish predation in determining chlorophyll- $a$ concentrations and water transparency. Keywords: shallow saline lakes, zooplankton biomass, fish predation, top down.
\end{abstract}

ECHANIZ, S.A., VIGNATTI, A.M., CABRERA, G.C. \& PAGGI, S.B.J. Riqueza, abundancia y biomasa zooplanctónica de dos lagos someros hipertróficos de distinta salinidad de la región central de Argentina. Biota Neotrop. v. 12 (1): http://www.biotaneotropica.org.br/v12n2/pt/abstract?article+bn00712022012

Resumen: El zooplancton lacustre es controlado por parámetros biológicos y fisicoquímicos. Entre los primeros, la depredación por peces puede determinar el reemplazo de especies de talla grande por pequeñas y entre los segundos la salinidad ejerce efectos negativos sobre la riqueza y abundancia. Dado que se ha indicado que los lagos salinos sin peces tienen mayores biomasas zooplanctónicas que los de baja salinidad, el objetivo de este trabajo es conocer la riqueza, abundancia y biomasa del zooplancton de dos lagos de diferente salinidad y probar la hipótesis de que a iguales concentraciones de nutrientes y clorofila "a" los lagos salinos tienen mayor biomasa que los de baja salinidad. El estudio se desarrolló en dos lagos de la provincia de La Pampa, en el centro de Argentina, uno subsalino y otro hiposalino, que compartieron elevadas concentraciones de clorofila $a$ y fósforo total, reducida transparencia y presencia de un pez planctófago. Aunque la riqueza resultó diferente y más elevada en el lago subsalino, no ocurrió lo mismo con la abundancia y biomasa totales, ni al considerar los grupos taxonómicos por separado. La presencia de un pez planctívoro halotolerante controló la talla del zooplancton debido a la depredación sobre las especies de mayor tamaño e impidió el desarrollo de mayor biomasa en el lago salino, lo que constituye una importante diferencia con situaciones registradas anteriormente. Este estudio mostró que a pesar de la diferencia en la salinidad, el efecto en cascada en la cadena trófica (top down) es un factor que iguala la biomasa zooplanctónica al permitir sólo el desarrollo de especies pequeñas y pone en evidencia la importancia de la depredación por peces en la determinación de las concentraciones de clorofila y transparencia del agua.

Palabras clave: lagos someros salinos, biomasa zooplanctónica, depredación, cascada trófica. 


\section{Introduction}

The zooplankton of lakes is a key component of the ecology of water bodies because these organisms feed on phytoplankton, recycle the nutrients through excretion, and represent an important prey to many predators. Their composition, abundance and biomass are controlled by biotic and abiotic parameters. The former include the availability and quality of food resources, interspecific competition and predation by vertebrates and invertebrates (Lampert \& Sommer 1997, Khan et al. 2003, Chang et al. 2004, Boveri \& Quirós 2007, Manca et al. 2008). The negative effects of poor quality food supply are known (DeMott et al. 2001, Wilson \& Hay 2007) as is the fact that the predation by zooplanktivorous fish produces the replacement of larger species by smaller ones is also known (Brooks \& Dodson 1965). This, in turn, leads to changes in grazing pressure and phytoplankton biomass (top-down effect) (Bertolo et al. 2000, Kalff 2002, Boveri \& Quirós 2007, Manca et al. 2008).

Among the abiotic parameters, the structure of zooplankton is affected by the concentration of dissolved solids, the temperature, the size and land use of the basins, and environmental heterogeneity, because the higher number of habitats offered by larger lake environments exerting positive effects on the richness and abundance of zooplankton (Kobayashi 1997, Hobæk et al. 2002, Kalff 2002, Hall \& Burns 2003, Dodson et al. 2007). In addition, it is known that an increase in salinity may exert negative effects on the richness and abundance of zooplankton (Herbst 2001, Ivanova \& Kazantseva 2006). It has also been reported that salinity favors indirectly the secondary production of zooplankton, because saline lakes tend to lack fish fauna, which allows the development of larger zooplankton species and therefore to have higher biomass of zooplankton than low salinity lakes, although they have lower phytoplankton biomass and chlorophyll- $a$ concentrations (Campbell \& Prepas 1986, Evans et al. 1996).

Shallow lakes, in general, do not exceed three meters in depth, and are not stratified because of the mixing effect of the wind. Such water-bodies usually have a high trophic state (Scheffer 1998,
Quirós et al. 2002, Scheffer \& Jeppesen 2007, Grosman 2008) and those with total dissolved solids concentrations greater than 3 g.L. $\mathrm{L}^{-1}$ are classified as saline (Hammer 1986).

In the central semiarid region of Argentina (Province of La Pampa), there are many shallow lakes with a wide range of concentrations of dissolved solids, ranging from subsaline to hypersaline (Echaniz et al. 2006, Vignatti et al. 2007). Many of these lakes have suffered marked deterioration due to the human activities carried out in their basins, such as livestock breeding, growing of cereal and oilseed crops and development of urbanized areas of increasing size. Although most are temporary and clear, anthropogenic influence has led many lakes become permanent, or to become turbid due to the introduction of fish, particularly the zooplanktivorous Odontesthes bonariensis (Cuvier and Valenciennes 1835) (Echaniz et al. 2008, 2009, 2010a,b).

We have previously carried out several studies on the composition and density of zooplankton in several shallow lakes of La Pampa (Echaniz et al. 2006, 2008, 2009, 2010b, Vignatti et al. 2007), but not compared the zooplankton biomass in the studied environments. Therefore, the aim of this study was to determine the taxonomic composition, abundance and biomass of zooplankton in two shallow lakes of La Pampa with different salinity and test the hypothesis that in presence of zooplanktivorous fishes and at equal concentrations of nutrients and chlorophyll- $a$, saline lakes have higher biomass of zooplankton than lakes of low salinity.

\section{Material and Methods}

\section{Study area}

The study was conducted in two permanent shallow lakes located in the vicinity of the city of Santa Rosa, La Pampa Province, Argentina: the Bajo de Giuliani and Don Tomás (Figure 1).

The Bajo de Giuliani lake ( $64^{\circ} 15^{\prime} \mathrm{W}$ and $\left.36^{\circ} 41^{\prime} \mathrm{S}\right)$ is hyposaline (Hammer 1986) and has a surface of 1171.3 ha and a maximum depth of $2.8 \mathrm{~m}$. It is located $10 \mathrm{~km}$ south of the city of Santa Rosa, in a deep arheic depression. Most of its perimeter is surrounded by fields

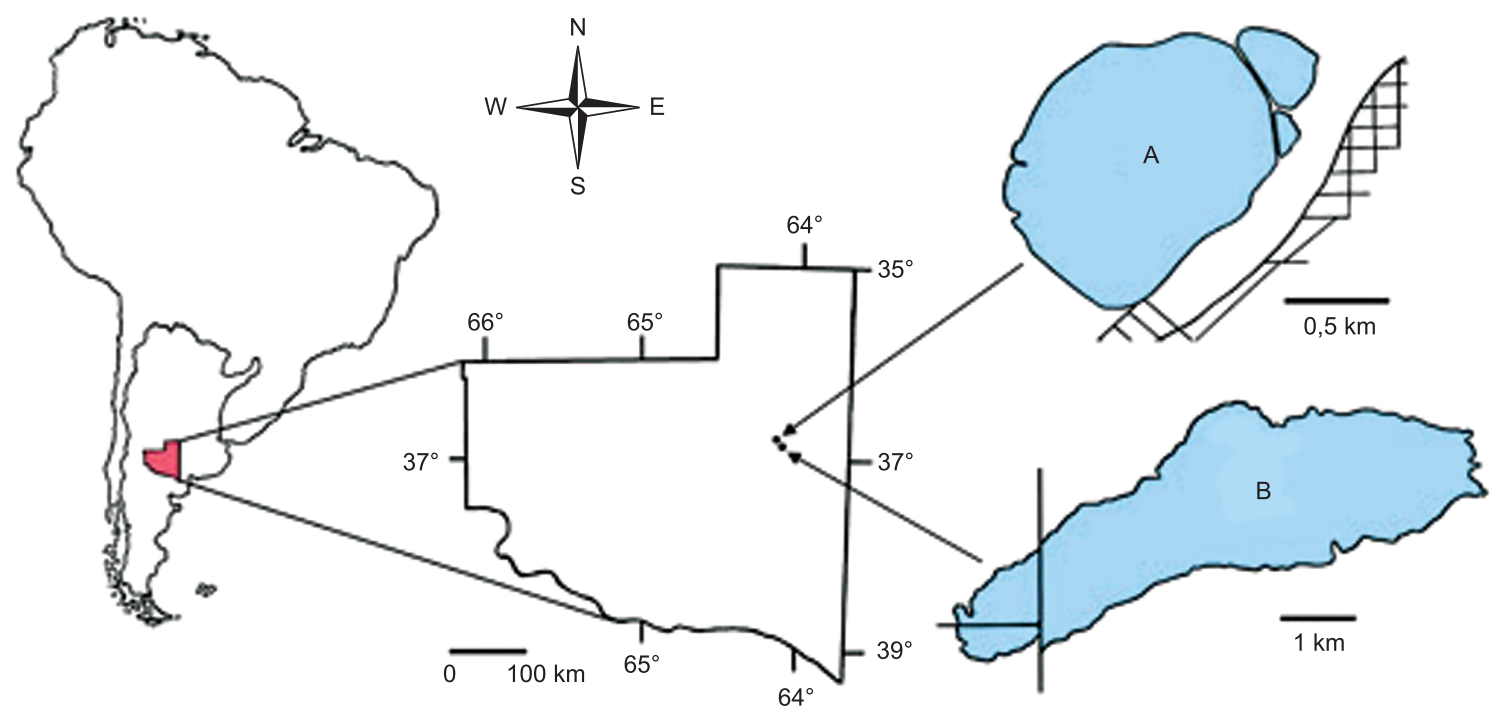

Figure 1. Geographical location and sketch of studied lakes. A: Don Tomás. B: Bajo de Giuliani.

Figura 1. Ubicación geográfica de los lagos estudiados. A: Don Tomás. B: Bajo de Giuliani. 
used for farming, especially cattle breeding. In addition, it is the final recipient of the sewage treatment plant of the city.

Don Tomás Lake (64' $19^{\prime} \mathrm{W}$ and $36^{\circ} 37^{\prime} \mathrm{S}$ ) is subsaline (Hammer 1986) and has a surface of 148.3 ha and a maximum depth of $2.3 \mathrm{~m}$. It is near the city of Santa Rosa and receives the input from storm drains. Under normal conditions, it does not receive sewage, although this may occur when heavy rains fill and overflow pipes. Since its perimeter has been rectified and dredged, it is very regular, almost circular.

Both environments have high organic turbidity, absence of aquatic vegetation, and presence of the planktivorous species Odontesthes bonariensis (Rosso 2006, Boveri \& Quirós 2007).

\section{Field work}

Samplings were carried out at three sites in the limnetic region in each lake during each season of 2006 and 2007 (January, April, July and October). Water temperature, dissolved oxygen (oximeter Lutron OD 5510), and water transparency (Secchi disk) were determined in situ. Water samples were collected and refrigerated for physical and chemical analysis and determination of chlorophyll- $a$ concentrations. Since no significant differences were found between the values of the environmental variables measured at each site of the two lakes, the mean values were used for the analysis.

Quantitative zooplankton samples were collected at each site, with a $10 \mathrm{~L}$ capacity Schindler-Patalas trap equipped with a $0.04 \mathrm{~mm}$ mesh size, at three depths that were integrated into a single sample which represented a total filtrate volume of $30 \mathrm{~L}$. Qualitative samples also were taken by vertical and horizontal drags with a net of $22 \mathrm{~cm}$ mouth diameter and $0.04 \mathrm{~mm}$ mesh size. All the samples were anesthetized with $\mathrm{CO}_{2}$ and kept refrigerated until measurements, with the aim of avoiding contractions that may deform the individuals collected. The samples were fixed with formalin 5-8\% and deposited in the plankton collection of the Facultad de Ciencias Exactas y Naturales de la Universidad Nacional de La Pampa, La Pampa Province, Argentina.

\section{Laboratory Work and Data Analysis}

The $\mathrm{pH}$ was determined by means of a Cornning PS $15 \mathrm{pH}$ meter, the conductivity with an Oakton TDSTestr 20 conductivity meter, and the concentration of dissolved solids by the method of solid residue. Chlorophyll- $a$ concentration was estimated by extraction with aqueous acetone with Microclar FFG047WPH filters and spectrophotometry (Metrolab 1700 spectrophotometer) (APHA 1992, Arar 1997), total nitrogen by the Kjeldahl method and total phosphorus by digestion of the sample with potassium persulfate in acidic medium and spectrophotometry (APHA 1992).

The content of organic and inorganic suspended solids was determined by filtering a known volume of water through Microclar FFG047WPH filters, dried at 103 to $105^{\circ} \mathrm{C}$ to constant weight and then calcined at $550{ }^{\circ} \mathrm{C}(\mathrm{EPA} 1993)$.

The density of macro and microzooplankton (Kalff 2002) was estimated with a stereomicroscope and conventional optical microscope in Bogorov and Sedgwick-Rafter chambers respectively. To determine the biomass of zooplankton, a minimum of 30 specimens of all species were measured with a Carl Zeiss ocular micrometer and formulas that relate the total length with the dry weight of the specimens were used (Ruttner-Kolisko 1977, Dumont et al. 1975, Rosen 1981, McCauley 1984, Culver et al. 1985).

The physical, chemical and biological differences were tested by nonparametric Kruskal-Wallis analysis of variance and the relationships between the environmental factors and the zooplankton features were assessed by Spearman correlation $\left(\mathrm{r}_{\mathrm{s}}\right.$ ) (Sokal \& Rohlf 1995, Zar 1996) and Principal Components Analysis (PCA) (Pérez
2004, Mangeaud 2004), using Past (Hammer et al. 2001) and Infostat (Di Rienzo et al. 2010) softwares.

\section{Results}

\section{Abiotic parameters}

Water temperature followed a similar seasonal pattern in both lakes, and although the mean was slightly lower in Don Tomás, the differences were not significant (Table 1).

The concentration of dissolved solids ranged between 0.64 and 1.16 g.L. ${ }^{-1}$ in Don Tomás, and between 9.64 and 11.2 g.L.- in Bajo de Giuliani (Figure 2), being this a significant difference (Table 1).

Water transparency in both lakes was low and ranged between 0.11 and $0.22 \mathrm{~m}$, but there were no significant differences between the values (Table 1). No significant correlations were found between transparency and chlorophyll- $a$ or suspended solids concentrations.

The average concentration of nutrients was very high in both water bodies and there were significant differences only in total nitrogen (Table 1). No significant correlation was found between the concentrations of both nutrients. The $\mathrm{pH}$ and dissolved oxygen concentration were different and higher in Bajo de Giuliani (Table 1).

The concentrations of inorganic and organic suspended solids in both lakes were different (Table 1) and correlation was found only between the latter parameter and dissolved solids $\left(r_{s}=0.69\right.$, $\mathrm{p}=0.0033)$.

\section{Chlorophyll-a concentrations and zooplankton}

The phytoplanktonic chlorophyll- $a$ concentration was high in both lakes, and fluctuated between $88.8 \mathrm{mg} \cdot \mathrm{m}^{-3}$ (Don Tomás) and 352.4 mg. $\mathrm{m}^{-3}$ (Bajo de Giuliani), although the differences were not significant (Table 1, Figure 3). A significant correlation was found only between chlorophyll- $a$ and TN concentrations $\left(r_{s}=0.65\right.$, $\mathrm{p}=0.0063)$.

A total of 33 taxa were recorded: 7 cladocerans, 6 copepods and 20 rotifers. The number of species was significantly different $(\mathrm{H}=8.91, \mathrm{p}=0.0028)$ between the lakes: 26 were found in Don Tomás and 17 in Bajo de Giuliani (Table 2). While seven taxa were recorded only in Bajo de Giuliani and 16 only in Don Tomás, two cladocerans, one copepod and seven rotifers were recorded in both water bodies (Table 2).

The (PCA), whose first two components explained almost $50 \%$ of the total variance, showed the negative influences of the concentration of total dissolved solids and suspended solids on the cladocerans

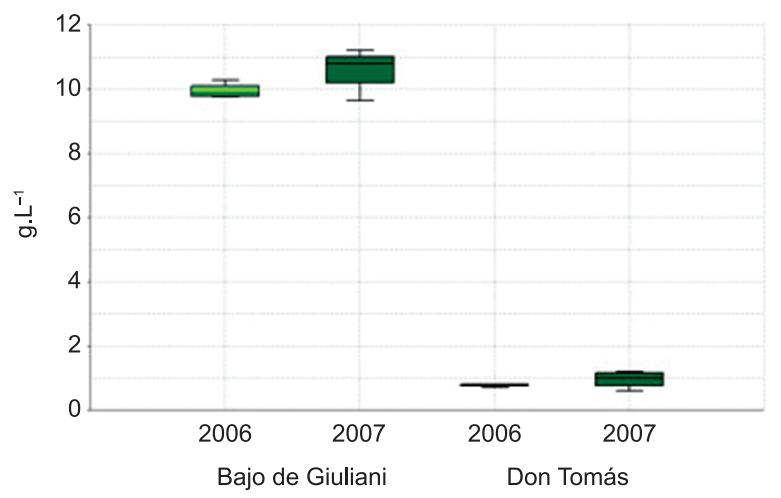

Figure 2. Dissolved solids concentrations in the water of both studied lakes. Figura 2. Concentración de sólidos disueltos en el agua de las dos lagunas estudiadas. 
Echaniz, S.A. et al.

Table 1. Main limnological parameters of the studied lakes (means and standard deviations) and results of Kruskal Wallis test (K.W.) (*indicates significative differences)

Tabla 1. Principales parámetros limnológicos medidos en los lagos someros estudiados (promedios y desviaciones estándar) y resultados del test de Kruskal Wallis (K.W.) (*indica diferencias significativas).

\begin{tabular}{|c|c|c|c|}
\hline & Bajo de Giuliani & Don Tomás & K.W. \\
\hline Water temperature & $\mathbf{1 7 . 6} \pm 8.1$ & $16.7 \pm 7.3$ & $\begin{array}{c}H=0.01 \\
p=0.9164\end{array}$ \\
\hline Transparency (m) & $\mathbf{0 . 1 7} \pm 0.04$ & $\mathbf{0 . 1 6} \pm 0.04$ & $\begin{array}{c}H=0.34 \\
p=0.5603\end{array}$ \\
\hline Total dissolv. solids $\left(\mathrm{g} . \mathrm{L}^{-1}\right)^{*}$ & $10.27 \pm 0.58$ & $\mathbf{0 . 8 7} \pm 0.18$ & $\begin{array}{l}H=11.29 \\
p=0.0008\end{array}$ \\
\hline Conductivity $\left(\mathrm{mS} . \mathrm{cm}^{-1}\right)^{*}$ & $16.9 \pm 1.04$ & $\mathbf{1 . 4 8} \pm 0.23$ & $\begin{array}{c}H=11.31 \\
p=0.0008\end{array}$ \\
\hline $\mathrm{pH}^{*}$ & $9.1 \pm 0.15$ & $8.4 \pm 0.50$ & $\begin{array}{c}H=9.83 \\
p=0.0201\end{array}$ \\
\hline Total phosphorus (mg. $\mathrm{L}^{-1}$ ) & $8.91 \pm 2.81$ & $6.57 \pm 4.50$ & $\begin{array}{c}H=7.12 \\
p=0.0682\end{array}$ \\
\hline Total nitrogen $\left(\mathrm{mg} . \mathrm{L}^{-1}\right)^{*}$ & $\mathbf{1 8 . 7 7} \pm 4.91$ & $\mathbf{1 0 . 1 6} \pm 2.13$ & $\begin{array}{c}H=8.46 \\
p=0.0375\end{array}$ \\
\hline Dissolved oxigen $\left(\mathrm{mg} . \mathrm{L}^{-1}\right)^{*}$ & $\mathbf{1 2 . 4 1} \pm 3.10$ & $8.79 \pm 1.35$ & $\begin{array}{c}H=9.71 \\
p=0.0212\end{array}$ \\
\hline Inorg. susp. solids $\left(\mathrm{mg} . \mathrm{L}^{-1}\right)^{*}$ & $\mathbf{3 8 . 0 5} \pm 27.3$ & $\mathbf{4 . 0 3} \pm 4.6$ & $\begin{array}{c}H=6.35 \\
p=0.0117\end{array}$ \\
\hline Org. susp. solids $\left(\mathrm{mg} . \mathrm{L}^{-1}\right)^{*}$ & $89.33 \pm 14.83$ & $\mathbf{5 2 . 0 5} \pm 13.15$ & $\begin{array}{c}H=9.94 \\
p=0.0016\end{array}$ \\
\hline Chl $a\left(\mathrm{mg} \cdot \mathrm{m}^{-3}\right)$ & $201.16 \pm 69.74$ & $143.5 \pm 45.02$ & $\begin{array}{c}H=5.28 \\
p=0.1524\end{array}$ \\
\hline
\end{tabular}

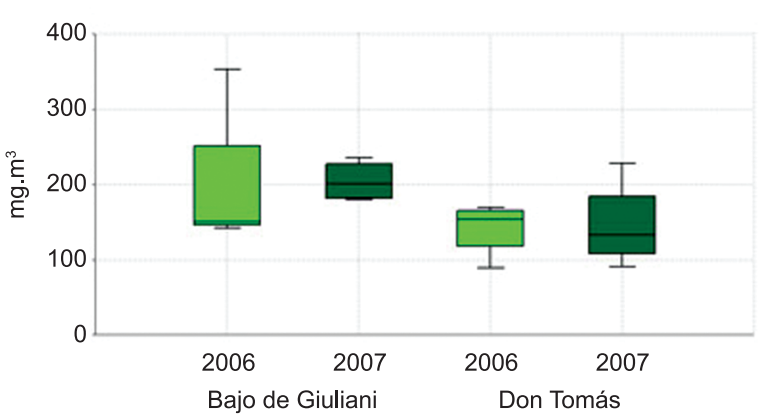

Figure 3. Phytoplanktonic chlorophyll- $a$ concentration in both studied lakes.

Figura 3. Concentración de clorofila- $a$ fitoplanctónica de las dos lagunas estudiadas.

and rotifers richness. In contrast, both parameters showed a positive influence on the number of copepod species (Figure 4).

The most common crustaceans in Don Tomás were Eubosmina huaronensis (Delachaux, 1918), Acanthocyclops robustus (G.O. Sars, 1863) and Microcyclops anceps (Richard, 1897), the latter was the most abundant species (mean $=707.5 \pm 1051.1$ ind. $\mathrm{L}^{-1}$ ). The crustaceans most frequently recorded in Bajo de Giuliani were Cletocamptus deitersi (Richard, 1897), Boeckella poopoensis Marsh, 1906 and Metacyclops mendocinus (Wierzejski, 1892); the latter reached the highest density $\left(\right.$ mean $=159.9 \pm 300.5$ ind. $\left.\mathrm{L}^{-1}\right)$.

The rotifers that predominated in both lakes belonged to the genus Brachionus. B. angularis Gosse, 1851 and B. dimidiatus

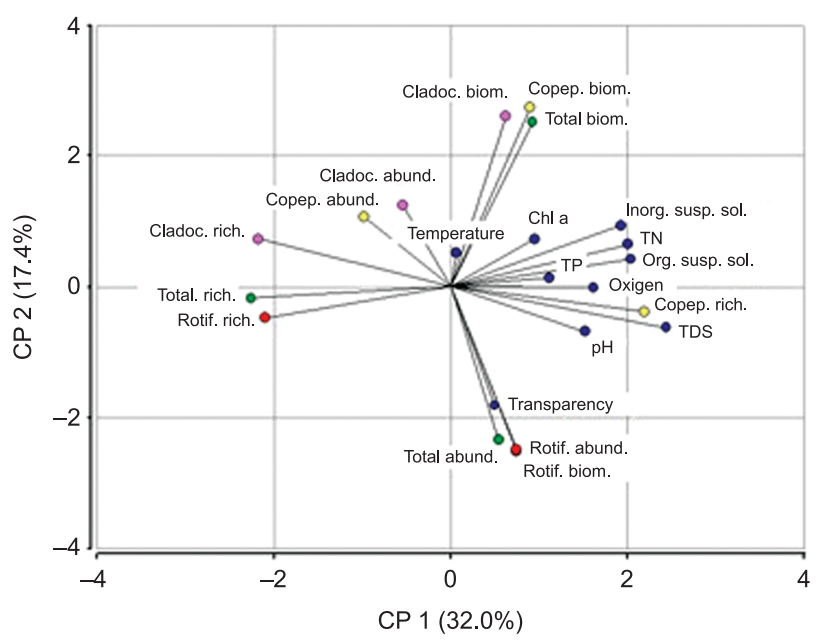

Figure 4. Biplot of the Principal Component Analysis (PCA).

Figura 4. Resultados del análisis de componentes principales (ACP).

Bryce, 1931 were the most frequent species in Don Tomás, although the most abundant species was B. plicatilis Müller, 1786 $\left(\right.$ mean $=208.7 \pm 586.4$ ind. $\left.\mathrm{L}^{-1}\right)$. In Bajo de Giuliani, the most frequent were B. ibericus Ciros-Pérez, Gómez \& Serra, 2001 and B. dimidiatus (Table 2), the latter being the one which reached the highest density $\left(\right.$ mean $=2114.4 \pm 4934.7$ ind. $\left.\mathrm{L}^{-1}\right)$.

No significant differences were found in zooplankton total abundance in both lakes, even when the taxonomic groups were considered separately (Table 3, Figure 5). The PCA showed that the total density was determined especially by the high abundances 
Table 2. Taxa registered in the studied shallow lakes and frequency in samples.

Tabla 2. Taxones registrados en los lagos someros estudiados y frecuencia de aparición en las muestras.

\begin{tabular}{|c|c|c|}
\hline Taxa & Bajo de Giuliani & Don Tomás \\
\hline \multicolumn{3}{|l|}{ Cladocera } \\
\hline Diaphanosoma birgei Korinek, 1981 & & 37.5 \\
\hline Moina micrura Kurz, 1874 & 12.5 & 50 \\
\hline Moina eugeniae Olivier, 1954 & 12.5 & \\
\hline Eubosmina huaronensis (Delachaux, 1918) & & 100 \\
\hline Daphnia menucoensis Paggi, 1996 & 25 & \\
\hline Daphnia spinulata Birabén, 1917 & 12.5 & 12.5 \\
\hline Alona sp. & & 37.5 \\
\hline \multicolumn{3}{|l|}{ Copepoda } \\
\hline Boeckella gracilis (Daday, 1902) & & 12.5 \\
\hline Boeckella poopoensis Marsh, 1906 & 87.5 & \\
\hline Microcyclops anceps (Richard, 1897) & & 100 \\
\hline Acanthocyclops robustus (G.O. Sars, 1863) & & 100 \\
\hline Metacyclops mendocinus (Wierzejski,1892) & 87.5 & \\
\hline Cletocamptus deitersi (Richard, 1897) & 100 & 12.5 \\
\hline \multicolumn{3}{|l|}{ Rotifera } \\
\hline Brachionus plicatilis Müller, 1786 & & 50 \\
\hline Brachionus ibericus Ciros-Pérez, Gómez \& Serra, 2001 & 62.5 & \\
\hline Brachionus havanaensis Rousselet, 1913 & 12.5 & 25 \\
\hline Brachionus angularis Gosse, 1851 & 37.5 & 62.5 \\
\hline Brachionus dimidiatus Bryce, 1931 & 62.5 & 50 \\
\hline Brachionus calyciflorus (Pallas, 1766) & & 12.5 \\
\hline Brachionus pterodinoides Rousselet, 1913 & 50 & 25 \\
\hline Brachionus caudatus Barrois \& Daday, 1894 & & 25 \\
\hline Brachionus quadridentatus Hermann, 1783 & & 25 \\
\hline Keratella tropica (Apstein, 1907) & 12.5 & 75 \\
\hline Keratella cochlearis (Gosse, 1851) & 12.5 & 37.5 \\
\hline Hexarthra intermedia (Wiszniewski, 1929) & & 25 \\
\hline Hexarthra fennica (Levander, 1892) & 12.5 & \\
\hline Polyarthra dolichoptera Idelson, 1925 & & 50 \\
\hline Lepadella acuminata (Ehrenberg, 1834) & & 12.5 \\
\hline Lecane sp. & & 25 \\
\hline Lecane lunaris (Ehrenberg, 1832) & 12.5 & 12.5 \\
\hline Lecane bulla (Gosse, 1851) & & 25 \\
\hline Anuraeopsis fissa (Gosse, 1851) & 12.5 & \\
\hline Pompholyx complanata Gosse, 1851 & & 25 \\
\hline Richness & 17 & 26 \\
\hline
\end{tabular}

of rotifers and that it was positively affected by water transparency (Figure 4).

When analyzing the abundance of the taxonomic groups separately, the PCA showed a positive relationship between the abundance of cladocerans and copepods and water temperature, but a negative relationship with the concentration of dissolved solids (Figure 4).

The average size of zooplankton in Bajo de Giuliani was $413.5 \mu \mathrm{m} \pm 286.3$, whereas in Don Tomás this value was slightly lower $(295.74 \mu \mathrm{m} \pm 109.4)$, but the difference was not significant.

The biomass of zooplankton in both lakes was similar (Figure 6), since no significant differences were found in total biomass or when considering the taxonomic groups separately (Table 3 ).
Zooplankton biomass was not influenced by the concentration of dissolved solids, but was positively influenced by the concentrations of chlorophyll- $a$ and inorganic suspended solids (Figure 4). Copepods and cladocerans were the ones that contributed most to the total biomass in both lakes.

Among the crustaceans of Bajo de Giuliani, the greatest mean biomass was provided by $B$. poopoensis $\left(1510.6 \pm 2234.5 \mu \mathrm{g} . \mathrm{L}^{-1}\right)$ followed by $M$. mendocinus $\left(511.4 \pm 1034.2 \mu \mathrm{g} . \mathrm{L}^{-1}\right)$, and, among the rotifers, by $B$. ibericus $\left(258.8 \pm 435.8 \mu \mathrm{g}\right.$. $\left.\mathrm{L}^{-1}\right)$. In Don Tomás, $M$. anceps contributed with the highest mean crustacean biomass $\left(1505.7 \pm 1212.9 \mu \mathrm{g} . \mathrm{L}^{-1}\right)$ and $B$. plicatilis with the highest mean rotifer biomass $\left(49.9 \pm 125.7 \mu \mathrm{g} . \mathrm{L}^{-1}\right)$.

In Bajo de Giuliani, the zooplankton biomass presented its peaks in spring (3375.6 and 8375.6 in 2006 and 2007 respectively), 
Echaniz, S.A. et al.

Table 3. Mean abundance and biomass (in bold), minimum and maximum (in italics) by taxonomic group and total zooplankton in both lakes and results of Kruskal Wallis test. (BG: Bajo de Giuliani, DT: Don Tomás).

Tabla 3. Abundancia y biomasa medias (en negritas), mínimas y máximas (en cursivas) por grupo taxonómico y del total del zooplancton de ambas lagunas y resultados del test de Kruskal Wallis. (BG: Bajo de Giuliani, DT: Don Tomás).

\begin{tabular}{|c|c|c|c|c|c|c|}
\hline & \multicolumn{3}{|c|}{ Abundance (ind. $\mathrm{L}^{-1}$ ) } & \multicolumn{3}{|c|}{ Biomass $\left(\mu \mathrm{g} . \mathrm{L}^{-1}\right)$} \\
\hline & BG & DT & K.W. & BG & DT & K.W. \\
\hline \multirow{2}{*}{ Cladocera } & 11 & 130.6 & $\mathrm{H}=2.84$ & 298 & 257 & $\mathrm{H}=0.89$ \\
\hline & $0-70.5$ & $1.4-771.6$ & $\mathrm{p}=0.0919$ & $0-2246$ & $1.4-1071.7$ & $\mathrm{p}=0.3431$ \\
\hline \multirow{2}{*}{ Copepoda } & 295.4 & 758.6 & $\mathrm{H}=0.54$ & 2030.6 & 1547.7 & $\mathrm{H}=0.11$ \\
\hline & $23-892$ & $15.2-3813$ & $\mathrm{p}=0.4623$ & $180.7-6119$ & $38.9-3834$ & $\mathrm{p}=0.7527$ \\
\hline \multirow{2}{*}{ Rotifera } & 7060.3 & 510.6 & $\mathrm{H}=0.89$ & 390.2 & 87.9 & $H=0.39$ \\
\hline & $47-3399$ & $10-1840$ & $\mathrm{p}=0.3446$ & $5.9-1549$ & $1.2-388.4$ & $\mathrm{p}=0.5286$ \\
\hline \multirow{2}{*}{ Total } & 7768.4 & 2174.3 & $\mathrm{H}=0.54$ & 2850.2 & 2120.9 & $\mathrm{H}=0.18$ \\
\hline & $261.1-34495$ & $87-8291$ & $\mathrm{p}=0.4623$ & $341.3-8376$ & $48.6-4612.4$ & $\mathrm{p}=0.6744$ \\
\hline
\end{tabular}

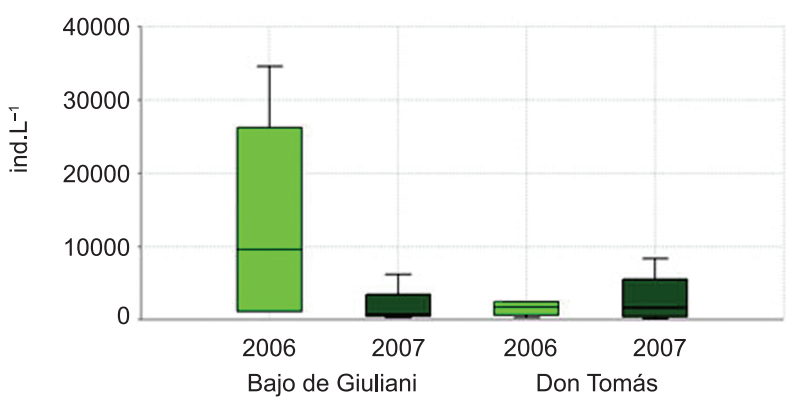

Figure 5. Annual zooplanktonic abundance in both studied lakes.

Figura 5. Densidad zooplanctónica anual de las dos lagunas estudiadas.

whereas, in Don Tomás, peaks were in spring 2006 (4612.4 $\left.\mu \mathrm{g} . \mathrm{L}^{-1}\right)$ and in summer 2007 (3753.7 $\left.\mu \mathrm{g} . \mathrm{L}^{-1}\right)$. No correlation was found between the zooplankton biomass and the abiotic variables, and when considering the groups separately. The relationship was significant only between the biomass of cladocerans and water temperature $\left(\mathrm{r}_{\mathrm{s}}=0.54, \mathrm{p}=0.0309\right)$.

\section{Discussion}

Although the two lakes differed in their salinity, they shared features such as high concentrations of phosphorus and reduced transparency (caused by high concentrations of chlorophyll- $a$ and organic and inorganic suspended solids), which allowed their categorization as hypertrophic environments (OECD 1982). According to the model of alternative states of shallow lakes, they are organic turbid environments (Torremorell et al. 2007, Allende et al. 2009) and their primary production is dominated by phytoplankton due to the absence of macrophytes.

The number of zooplankton taxa in both lakes differed because it was negatively influenced by the concentration of dissolved salts in the water. The higher zooplankton richness of Don Tomás, typical of subsaline environments, had been previously reported (Echaniz et al. 2008). In contrast, the lower number of taxa recorded in Bajo de Giuliani showed the modulating effect of the higher salt concentration, which means it can be inhabited by a smaller number of halotolerant species (Herbst 2001, Ivanova \& Kazantseva 2006).

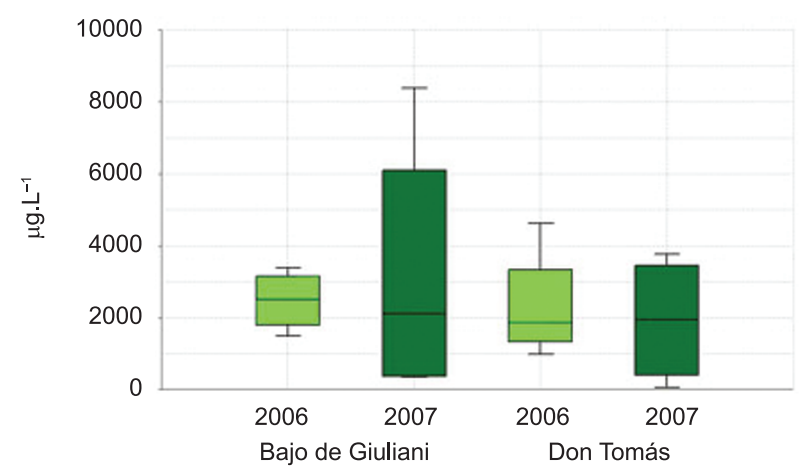

Figure 6. Zooplanktonic biomass in both studied lakes.

Figura 6. Biomasa zooplanctónica de los dos lagos someros estudiados.

Although some species were present in both lakes, the crustaceans E. huaronensis, A. robustus and M. anceps predominated in Don Tomás. These species are more commonly found in other environments of low salinity of La Pampa (Vignatti et al. 2007, Echaniz et al. 2008). The species that prevailed in Bajo de Giuliani were the halotolerants Cletocamptus deitersi, M. mendocinus and B. poopoensis (Menu-Marque \& Locascio de Mitrovich 1998, Echaniz et al. 2006, Vignatti et al. 2007). The highest number of shared species was recorded among rotifers and most of the taxa recorded were of cosmopolitan distribution (Segers \& De Smet 2008) and euryhaline (Fontaneto et al. 2006). The presence of large-sized cladocerans, especially that of the genus Daphnia, was sporadic and never reached high densities, possibly due to the predation exerted by fish (Grosman \& Sanzano 2003, Boveri \& Quirós 2007, Manca et al. 2008) present in both lakes. The high standard deviation values found in the abundance and biomass of both lakes were due to the pronounced seasonality of the pampean environments, that have produced marked differences in both parameters (Echaniz et al. 2006, 2009).

In Redberry Lake, Evans et al. (1996) found that, due to its high salinity, the lake lacked fish fauna, which constitutes an important difference with the lakes included in this study, which are characterized by fish fauna dominated by Odontesthes bonariensis, a very tolerant species that can inhabit water bodies with salinities of up to 35.8 g.L - $^{-1}$ (Rosso 2006, Mancini \& Grosman 2008). The lack of fish in Redberry Lake allowed the increased abundance of the large herbivorous zooplankton species, including Daphnia pulicaria 
Forbes, 1893, and the diaptomid copepods Diaptomus sicilis (Forbes, 1882) and Diaptomus nevadensis (Light, 1938). This, in turn, allowed the development of a high zooplankton biomass (Evans et al. 1996). In contrast, the presence of a visual planktivorous fish such as Odontesthes bonariensis (Rosso 2006, Boveri \& Quirós 2007) in the lakes of La Pampa prevents the development of large-sized zooplankton species (Quirós et al. 2002, Grosman \& Sanzano 2003, Rosso 2006, Boveri \& Quirós 2007). So, the composition of the zooplankton is dominated by rotifers and small crustaceans producing zooplanktonic communities of similar size, and resulted in no differences in biomass. The lower efficiency of the smaller zooplankton to filter the algae would have allowed the development of high phytoplankton biomass, with the consequent reduced transparency in the studied lakes.

Although it has been reported that lakes that exceed 1 g.L $\mathrm{L}^{-1}$ of salt tend to have lower phytoplanktonic biomass (expressed by the concentrations of chlorophyll- $a$ and higher zooplanktonic biomass than subsaline lakes with similar nutrient concentrations (Evans et al. 1996), the present study not found higher zooplanktonic or lower phytoplanktonic biomasses in Bajo de Giuliani lake. The study showed that the taxonomic composition and biomass of zooplankton seemed to depend largely on the effect of predation, evidencing the importance of the top-down effect exerted by planktivorous fish. Despite the wide difference in the concentration of dissolved solids recorded between the two lakes, it is suggested that the trophic cascade caused both chlorophyll- $a$ concentration and zooplankton abundance and biomass to show no significant differences between the two lakes.

\section{Acknowledgements}

We thank the Facultad de Ciencias Exactas y Naturales de la Universidad Nacional de La Pampa for financial support, the municipality of Santa Rosa, the Scheuber family for facilitating the access to the Bajo de Giuliani and the anonymous reviewers that with their work improved this contribution.

\section{References}

ALlende, L., TELL, G., ZAGARESE, H., TORREMORELl, A., PÉREZ, G., BUSTINGORRY, J., ESCARAY, R. \& IZAGUIRRE, I. 2009. Phytoplankton and primary production in clear-vegetated, inorganic-turbid and algal-turbid shallow lakes from the pampa plain (Argentina). Hydrobiologia 624:45-60. http://dx.doi.org/10.1007/ s10750-008-9665-9

AMERICAN PUBLIC HEALTH ASSOCIATION - APHA. 1992. Standard Methods for the Examination of Water and Wastewater. 18th ed. APHA, American Water Works Association - AWWA and Water Pollution Control Federation - WPCF, Washington.

ARAR, E.J. 1997. In Vitro Determination of Chlorophylls a, b, c1 + c2 and Pheopigments in Marine and Freshwater Algae by Visible Spectrophotometry. Method 446.0. U.S. Environmental Protection Agency. http://www.epa.gov/microbes/m446_0.pdf (último acesso em 20/04/2011).

Bertolo, A., LACRoiX, G., LeSCHER-Moutoué, F. \& CARDINAL-LEGRAND, C. 2000. Plankton dynamics in planktivoreand piscivore-dominated mesocosms. Arch. Hydrobiol. 147:327-349.

BOVERI, M. \& QUIRÓS, R. 2007. Cascading trophic effects in pampean shallow lakes: results of a mesocosm experiment using two coexisting fish species with different feeding strategies. Hydrobiologia 584:215-222. http://dx.doi.org/10.1007/s10750-007-0581-1

BROOKS, J. \& DODSON, S. 1965. Predation, body size and composition of plankton. Science 150(3692):28-35. PMid:17829740. http://dx.doi. org/10.1126/science. 150.3692 .28
CAMPBELL, C.E. \& PREPAS, E.E. 1986. Evaluation of factors related to the unusually low chlorophyll levels in prairie saline lakes. Can. J. Fish. Aquat. Sci. 43:846-854. http://dx.doi.org/10.1139/f86-104

CHANG, K., NAGATA, T. \& HANAZATO, T. 2004. Direct and indirect impacts of predation by fish on the zooplankton community: an experimental analysis using tanks. Limnology 5:121-124. http://dx.doi. org/10.1007/s10201-004-0116-7

CULVER, D.A., BOUCHERLE, M., BEAN D.J. \& FLETCHER, J.W. 1985. Biomass of freshwater crustacean zooplankton from length- weight regressions. Can. J. Fish. Aquat. Sci. 42(8):1380-1390. http://dx.doi. org/10.1139/f85-173

DEMOTT, W., GULATI, R. \& VAN DONK, E. 2001. Daphnia food limitation in three hypereutrophic Dutch lakes: Evidence for exclusion of large-bodied species by interfering filaments of cyanobacteria. Limnol. Oceanogr. 46(8):2054 -2060. http://dx.doi.org/10.4319/lo.2001.46.8.2054

DI RIENZO, J.A., CASANOVES, F., BALZARINI, M.G., GONZÁLEZ, L., TABLADA, M. \& ROBLEDO, C.W. 2010. InfoStat (versión 2010). Grupo InfoStat, FCA, Universidad Nacional de Córdoba, Argentina. http://www. infostat.com.ar/ (último acesso em 20/04/2011).

DODSON, S., EVERHART, W., JANDL, A. \& KRAUSKOPF, S. 2007. Effect of watershed land use and lake age on zooplankton species richness. Hydrobiologia 579:393-399. http://dx.doi.org/10.1007/s10750-0060392-9

DUMONT, H.J., VAN DER VELDE, I. \& DUMONT, S. 1975. The dry weight estimate of biomass in a selection of Cladocera, Copepoda and Rotifera from the plankton, periphyton and benthos of continental waters. Oecologia 19:75-97. http://dx.doi.org/10.1007/BF00377592

ECHANIZ, S.A., VIGNATTI, A.M., JOSÉ DE PAGGI, S., PAGGI, J.C. \& PILATI, A. 2006. Zooplankton seasonal abundance of South American saline shallow lakes. Int. Rev. Hydrobiol. 91:86-100. http://dx.doi. org/10.1002/iroh.200510803

ECHANIZ, S.A., VIGNATTI A.M. \& BUNINO, P.C. 2008. El zooplancton de un lago somero hipereutrófico de la región central de Argentina: Cambios después de una década. Biota Neotrop. 8(4): http://www.biotaneotropica. org.br/v8n4/pt/fullpaper?bn01008042008 (último acesso em 11/01/2012).

ECHANIZ, S.A., VIGNATTI, A.M. \& CABRERA, G.C. 2009. Características limnológicas de una laguna turbia orgánica de la provincia de La Pampa y variación estacional del zooplancton. Biol. Acuat. 26:71-82.

ECHANIZ, S.A., VIGNATTI, A.M., JOSÉ DE PAGGI, S.B. \& PAGGI, J.C. 2010a. Los nutrientes en los sedimentos de lagunas de La Pampa. Relación con la granulometría y uso de la tierra. In Congreso Pampeano del Agua. Gobierno de la Provincia de LA PAMPA, p.23-31. Libro de Trabajos. http://www.lapampa.gov.ar/publicacionesrechid/24625-librodel-3er-congreso-pampeano-del-agua-ano-2010.pdf (último acesso em 11/01/2012).

ECHANIZ, S.A., VIGNATTI, A.M., JOSÉ DE PAGGI, S.B., PAGGI J.C. \& CABRERA, G.C. 2010b. El modelo de estados alternativos de lagos someros en La Pampa: comparación de Bajo de Giuliani y El Carancho. In Congreso Pampeano del Agua. Gobierno de la Provincia de LA PAMPA, p.45-53. Libro de Trabajos. http://www.lapampa.gov.ar/ publicacionesrechid/24625-libro-del-3er-congreso-pampeano-del-aguaano-2010.pdf. (último acesso em 11/01/2012).

ENVIRONMENTAL PROTECTION AGENCY - EPA. 1993. ESS Method 340.2: Total Suspended Solids, Mass Balance (Dried at 103-105 ${ }^{\circ} \mathrm{C}$ ) Volatile Suspended Solids (Ignited at $550{ }^{\circ} \mathrm{C}$ ). EPA. http://www.epa. gov/glnpo/lmmb/methods/methd340.pdf. (último acesso em 20/04/2011).

EVANS, M., ARTS, M. \& ROBARTS, R. 1996. Algal productivity, algal biomass, and zooplankton biomass in a phosphorus-rich saline lake: deviations from regression model predictions. Can. J. Fish. Aquat. Sci. 53:1048-1060. http://dx.doi.org/10.1139/f96-037

FONTANETO, D., DE SMET, W. \& RICCI, C. 2006. Rotifers in saltwaters, reevaluation of an inconspicuos taxon. J. Mar. Biol. Assoc. U.K. 86:623-656. http://dx.doi.org/10.1017/S0025315406013531

GROSMAN, F. 2008. Espejos en la llanura: Nuestras lagunas de la región pampeana. Editorial Universidad Nacional del Centro de la Provincia de Buenos Aires, Buenos Aires. 
GROSMAN, F. \& SANZANO, P. 2003. El pejerrey ¿puede causar cambios estructurales en un ecosistema? Biol. Acuat. 20:37-44.

HALL, C. \& BURNS, C. 2003. Responses of crustacean zooplankton to seasonal and tidal salinity changes in the coastal Lake Waihola, New Zealand. New Zealand J. Mar. Freshw. Res. 37:31-43. http://dx.doi.org/ $10.1080 / 00288330.2003 .9517144$

HAMMER, Ø., HARPER, D.A.T. \& RYAN, P.D. 2001. PAST: Paleontological Statistics Software Package for Education and Data Analysis. Palaeontol. Elect. 4(1):1-9.

HAMMER, U.T. 1986. Saline Lake Ecosystems of the World. Monographiae Biologicae 59. Dr. W. Junk Publishers, Dordrecht.

HERBST, D. 2001. Gradients of salinity stress, environmental stability and water chemistry as a templet for defining habitat types and physiological strategies in inland salt waters. Hydrobiologia 466:209-219. http://dx.doi. org/10.1023/A:1014508026349

HOBÆK, A., MANCA, M. \& ANDERSEN, T. 2002. Factors influencing species richness in lacustrine zooplankton. Acta Oecol. 23:155-163. http://dx.doi.org/10.1016/S1146-609X(02)01147-5

IVANOVA, M. \& KAZANTSEVA, T. 2006. Effect of Water pH and Total Dissolved Solids on the Species Diversity of Pelagic Zooplankton in Lakes: A Statistical Analysis. Russ. J. Ecol. 37(4):264-270. http://dx.doi. org/10.1134/S1067413606040084

KALFF, J. 2002. Limnology. Inland Water System. Prentice Hall, New Jersey. $592 \mathrm{p}$.

KHAN, T., WILSON, M. \& KHAN, M. 2003. Evidence for invasive carp mediated trophic cascade in shallow lakes of western Victoria, Australia. Hydrobiologia 506-509:465-472. http://dx.doi.org/10.1023/ B:HYDR.0000008558.48008.63

KOBAYASHI, T. 1997. Associations between environmental variables and zooplankton body masses in a regulated Australian river. Mar. Freshw. Res. 48:523-529. http://dx.doi.org/10.1071/MF96081

LAMPERT, W. \& SOMMER, U. 1997. Limnoecology:The ecology of lakes and streams. Oxford University Press, London. 382 p.

MANCA, M., VIJVERBERG, J., POLISHCHUK, L. \& VORONOV, D. 2008. Daphnia body size and population dynamics under predation by invertebrate and fish predators in Lago Maggiore: an approach based on contribution analysis. J. Limnol. 67(1):15-21. http://dx.doi.org/10.4081/ jlimnol.2008.15

MANCINI, M. \& GROSMAN, F. 2008. El pejerrey de las lagunas pampeanas: Análisis de casos tendientes a una gestión integral de las pesquerías. Editorial Universidad Nacional de Río Cuarto.

MANGEAUD, A. 2004. La aplicación de técnicas de ordenación multivariadas en la entomología. Rev. Soc. Entomol. Argent. 63(3-4):1-10.
McCAULEY, E. 1984. The estimation of the abundance of biomass of zooplankton in samples. In A manual on methods for the assessment of secondary productivity in freshwaters (J.A. Downing \& F. Rigler, eds.). Blackwell Sci. Publishers, London, p.228-265.

MENU-MARQUE, S. \& LOCASCIO DE MITROVICH, C. 1998. Distribución geográfica de las especies del género Boeckella (Copepoda, Calanoida, Centropagidae) en la República Argentina. Physis, B 56:1-10.

ORGANIZATION FOR ECONOMIC COOPERATION AND DEVELOPMENT - OECD. 1982. Eutrophication of waters. Monitoring, Assesment and Control. OECD, París. Final report.

PÉREZ, C. 2004. Técnicas de análisis multivariante de datos. Pearson Educación S.A., Madrid.

QUIRÓS, R., RENNELLA, A., BOVERI, M., ROSSO, J. \& SOSNOVSKY, A. 2002. Factores que afectan la estructura y el funcionamiento de las lagunas pampeanas. Ecol. Aust. 12:175-185.

ROSEN, R.A. 1981. Length - dry weight relationships of some freshwaters zooplankton. J. Freshwater Ecol. 1: 225-229. http://dx.doi.org/10.1080/ 02705060.1981 .9664034

ROSSO, J.J. 2006. Peces pampeanos: Guía y ecología. L.O.L.A. Literature of Latin America, Buenos Aires.

RUTTNER-KOLISKO, A. 1977. Suggestions for biomass calculation of plankton rotifers. Arch. Hydrobiol. 8:71-76.

SCHEFFER, M. 1998. Ecology of shallow lakes. Chapman \& Hall, London.

SCHEFFER, M. \& JEPPESEN, E. 2007. Regime Shifts in Shallow Lakes. Ecosystems 10:1-3. http://dx.doi.org/10.1007/s10021-006-9002-y

SEGERS, H. \& DE SMET, W. 2008. Diversity and endemism in Rotifera: a review, and Keratella Bory de St Vincent. Biodivers. Conserv. 17:303316. http://dx.doi.org/10.1007/s10531-007-9262-7

SOKAL, R. \& ROHLF, F. 1995. Biometría. Principios y métodos estadísticos en la investigación biológica. Ed. Blume, Barcelona.

TORREMORELL, A., BUSTINGORRY, J., ESCARAY, R. \& ZAGARESE, H. 2007. Seasonal dynamics of a large, shallow lake, laguna Chascomús: The role of light limitation and other physical variables. Limnologica 37:100-108. http://dx.doi.org/10.1016/j.limno.2006.09.002

VIGNATTI, A.M., ECHANIZ, S.A \& MARTÍN, M.C. 2007. El zooplancton de lagos someros de diferente salinidad y estado trófico en la región semiárida pampeana (La Pampa, Argentina). Gayana 71(1):38-48.

WILSON, A.E. \& HAY, M.E. 2007. A direct test of cyanobacterial chemical defense: Variable effects of microcystin-treated food on two Daphnia pulicaria clones. Limnol. Oceanogr. 52:1467-1479. http://dx.doi. org/10.4319/lo.2007.52.4.1467

ZAR, J.H. 1996. Biostatistical analysis. Prentice Hall, New Jersey. 